\title{
Non-invasive diagnostics in fossils - Magnetic Resonance Imaging of pathological belemnites
}

\author{
D. Mietchen ${ }^{1,2}$, H. Keupp ${ }^{3}$, B. Manz ${ }^{1}$, and F. Volke ${ }^{1}$ \\ ${ }^{1}$ Fraunhofer-Institute for Biomedical Engineering (IBMT), St. Ingbert, Germany \\ ${ }^{2}$ Faculty of Physics and Mechatronics, University of the Saarland, Saarbrücken, Germany \\ ${ }^{3}$ Institute of Geological Sciences, Freie Universität Berlin, Germany \\ Received: 21 February 2005 - Published in Biogeosciences Discussions: 14 March 2005 \\ Revised: 12 May 2005 - Accepted: 27 May 2005 - Published: 17 June 2005
}

\begin{abstract}
For more than a decade, Magnetic Resonance Imaging (MRI) has been routinely employed in clinical diagnostics because it allows non-invasive studies of anatomical structures and physiological processes in vivo and to differentiate between healthy and pathological states, particularly of soft tissue. Here, we demonstrate that MRI can likewise be applied to fossilized biological samples and help in elucidating paleopathological and paleoecological questions: Five anomalous guards of Jurassic and Cretaceous belemnites are presented along with putative paleopathological diagnoses directly derived from 3D MR images with microscopic resolution. Syn vivo deformities of both the mineralized internal rostrum and the surrounding former soft tissue can be traced back in part to traumatic events of predator-prey-interactions, and partly to parasitism. Besides, evidence is presented that the frequently observed anomalous apical collar might be indicative of an inflammatory disease. These findings highlight the potential of Magnetic Resonance techniques for further paleontological applications.
\end{abstract}

\section{Introduction}

Paleopathological studies can shed light on the ecology of ancient life forms, and they are helpful to evaluate the functional significance of morphological traits (Keupp, 1984, 1985). Most of the described paleopathological phenomena of fossil hard parts have a synecologial origin, i.e. they arose from interactions between different species (e.g. through predation, parasitism, epizoism). The specific reaction of the organism under attack lead to a characteristic syndrome whose symptoms often include anomalous growth patterns that can still be observed in fossil remains. The resulting degree of alterations in morphology always ranges within specific tol-

Correspondence to: D. Mietchen

(daniel.mietchen@ibmt.fraunhofer.de) erance limits and allows to estimate the functional relevance of distinct morphological features.

Within a wealth of paleopathological studies, most focus on vertebrates (cf. Tasnádi-Kubacska, 1962) but considerable efforts have also been directed towards pathological aspects of invertebrates - namely ectocochleate cephalopods, and ammonites in particular, research on which has a long scientific tradition (e.g. Engel, 1894; Hölder, 1956; Guex, 1967; Bayer, 1970; Keupp, 2000; Hengsbach, 1996; Kröger, 2000; Keupp, 1984, 1985). Descriptions and interpretations of anomalies in skeletons of endocochleate cephalopods, in contrast, appear only sporadically (for modern sepiids, see Ruggiero, 1980; Battiato, 1983; Ward and von Boletzky, 1984; von Boletzky and Overath, 1989; Bello and Paparella, 2002; for fossil squids, see Dietl and Schweigert, 2001). Notable exception are healed fractures in belemnite guards (see references in Keupp, 2002) which were seen as a proof of the endocochleate nature of the belemnite skeletons and gave rise to speculations about their function being, amongst other suggestions, a pushing weapon (Naef, 1922) or a digging tool (Abel, 1916). The reason for the different treatment of endoand ectocochleate specimens has a very practical nature: The shells of ectocochleate cephalopods allow sublethal injuries and other growth disturbances as well as the subsequent formation of characteristic syndromes of the attacked animal to be diagnosed immediately from anywhere in their posterior parts. Conventional investigations of anomalous belemnite guards, though, require to damage the rostrum in which former growth stages are surrounded by the later calcitic layers. Similar accessibility constraints apply to other types of specimens whose analysis by such invasive methodology, consequently, leads to considerable damage or even loss of the sample (Siveter et al., 2004). Our study, therefore, was designed to evaluate the potential of a non-invasive technique - Magnetic Resonance Imaging (MRI) - for paleontological applications, particularly in cases of rare anomalous fossils where it is especially desirable to avoid specimen destruc-

(C) 2005 Author(s). This work is licensed under a Creative Commons License. 
tion or to make informed decisions about how to sample invasively, where and how much.

\subsection{Magnetic resonance imaging}

The concept of Magnetic Resonance techniques and their applications in materials science and biomedical research have elsewhere been described in detail (e.g. Callaghan, 1991; Blümich and Kuhn, 1992; Boesch, 1999; Glover and Mansfield, 2002). In biomineralized samples, they have been employed for bone trabecular structure determinations in osteoporosis patients (Borah et al., 2001), for comparative studies on skeletal evolution (Spoor et al., 2000) as well as for indirect imaging of mouldic fossils after artificial filling with water as a contrast agent (Clark et al., 2004), and a short review on their potential for archeological investigations including resins, wood and semi-fossil bones is available (Lambert et al., 2000). Briefly, the spin of the nucleus of each atom possesses an isotope-specific resonance frequency directly proportional to the magnetic field strength it experiences. Thus, if irradiated by radiowaves at or very close to this frequency, a subpopulation of such an isotope can be excited. In a highly homogeneous field, subtle differences between the chemical bonds of different nuclei of the same species will translate into shifts of their resonance frequency, the recording of which is the basis of MR Spectroscopy. If, moreover, uniform magnetic field gradients are superimposed to the static field after excitation, the signal response which relaxes with two major time constants, $T_{1}$ and $T_{2}$, will contain frequencyencoded information about the spatial distribution of the excited nuclei, which allows for MR Imaging. In our study, only the signal of hydrogen nuclei (protons) within the fossils was detected. Depending on the chemical composition of a sample, on the gradient strengths and on the excitation pulse sequences used for data acquisition, the chemical and spatial information can be separated in MR images. The achievable image resolution depends on the relaxation constants, proton concentration and other MR parameters (Callaghan, 1991). Sample dimensions, moreover, depend on the type of spectrometer and on the dimensions of the gradient system as well as the probe, and structures - including cavities or pores - can be visualized as long as they result in changes of MR parameters. However, for the solid state samples investigated here, the signal intensity obtained for each volume element (voxel) mainly reflects its hydrogen content and is insensitive to properties of the chemical bonds that the protons in this voxel are engaged in. Therefore, a clear distinction of signals originating from organic or inorganic compounds of these belemnites is not possible.

1.2 Architecture and normal growth pattern of belemnite guards

The belemnite guard formed part of the endoskeleton of a squid-like decabrachiate coleoid and consists primarily of low-Mg calcite (Sælen, 1989). Its distal part (rostrum solidum or orthorostrum) is massive, the proximal part (rostrum cavum) surrounds the chambered aragonitic shell (phragmocone) that served as a buoyancy apparatus. The rostrum solidum is sometimes distally covered by an epirostrum that often appears hollow due to a presumably high primary content of organic or aragonitic material (Bandel and Spaeth, 1988). The guard is generally thought to have served as a counterweight to the soft body and was situated at the posterior portion of the orthoconic phragmocone, allowing the animal to maintain a horizontal swimming posture (Naef, 1922; Fischer, 1947; Stevens, 1965). The primary anlage of the rostrum was the cone-shaped "primordial guard" within the egg (Hanai, 1953; Jeletzky, 1966; Bandel et al., 1984). During ontogenesis, the rostrum thickened concentrically, and sometimes allometrically, by periodic accretions of radially arranged calcite prisms. The resulting microstructure is characterised by dominating radial calcite fibres with numerous relatively distinct growth lamellae that transverse the calcite prisms and become more closely spaced towards the outer margin of the guard. The original texture of the orthorostrum was solid, with an inner porosity of only $10 \%$ maximum (Veizer, 1974). Distinct concentric growth rings that cut the radially arranged crystals reflect phases of episodically reduced mineralisation that temporarily allowed integration of higher percentages of organic matter (Sælen, 1989), most of which has later been replaced by diagenetic calcite, as evidenced by data of stable isotopes $\left(\delta^{18} \mathrm{O}, \delta^{13} \mathrm{C}\right)$ and cathodoluminescence (Podlaha et al., 1998; O'Neill et al., 2002).

\subsection{Paleopathological phenomena}

Deformations of belemnite guards can result either from diagenetic, tectonic and impact events after the death of the organism or, during its life time, from illness or antibiotic interactions (predator-pray relationships, parasitism). Specimens of the latter group are collectively referred to as "pathological" (Keupp, 2002), and growth anomalies in juveniles are the focus of this study.

Pathological guards were described and interpreted for the first time by Duval-Jouve (1841) in sliced rostra with fractures. First attempts to extract evidence for behavioural traits of belemnoid animals from pathologic guards were made by Abel (1916) who attributed Duval-Jouve's rostral fractures to damage experienced when the animal used its posterior end as a digging tool, rather than to an unsuccessful attack by a predator. Consequently, he postulated a benthic way of life for these specimens. However, cuttlebone growth disturbances in modern cuttlefish living in their natural habitat are mostly triggered by repair of sublethal injuries as a consequence of unsuccessful attacks by predators - including human divers (von Boletzky and Overath, 1989). Correspondingly, it may be expected that many anomalous guards of belemnites reflect the repair of similar damages to the preadult rostrum or its muscular mantle. Nonetheless, it has 
been shown that - besides such exogenous traumatic events - remarkable anomalies also resulted from endogenous disturbances of the mantle tissue, including presumed cases of parasitism (Radwańska and Radwański, 2004).

\section{Sample description and method}

Five belemnite guards from the collection Keupp (PB), housed at the Institut of Geological Sciences, Freie Universität Berlin, Germany, were investigated. Hereafter, they will be referred to by their respective catalogue numbers. PB246, PB248 and PB249 are Gonioteuthis quadrata (Blainville, 1827) guards from the Late Cretaceous (Upper Campanian, ca. 75 Myr) marl pit "Alemannia”, Höver near Hannover, Germany. PB264 is a cast of a Neoclavibelus subclavatus (Voltz, 1830) rostrum from the Late Toarcian (Upper Liassic, ca. $182 \mathrm{Myr}$ ) of Mistelgau near Bayreuth, Germany. Our study has been performed on the original sample which is with V. Kriegisch, Schonungen, Germany. PB251 is a $\mathrm{Hi}$ bolithes jaculoides (Swinnerton, 1937) rostrum of the Lower Cretaceous (Late Hauterivian, ca. $118 \mathrm{Myr}$ ) from the coast of Helgoland Island, Germany. None of the samples were glued nor, to our knowledge, otherwise chemically conserved after excavation.

The MRI experiments were performed on a BRUKER Avance NMR spectrometer (Bruker, Rheinstetten, Germany) operating at a ${ }^{1} \mathrm{H}$ resonance frequency of $400 \mathrm{MHz}$ with standard Micro2.5 microimaging equipment and a maximum gradient strength of $0.4 \mathrm{~T} / \mathrm{m}$. Images were recorded using a standard $3 \mathrm{D}$ spin-echo imaging sequence (echo time $T_{e}=1.3 \mathrm{~ms}$, repetition time $T_{r}=1 \mathrm{~s}$ if not mentioned otherwise; for details, see Ernst et al., 1997). Each image consists of $128 \times 128 \times 256$ voxels. With typical sample dimensions of the order $10 \times 10 \times 30 \mathrm{~mm}^{3}$, this normally resulted in spatial resolutions around $100 \mu \mathrm{m}$. The total acquisition time $\left(T_{a}\right)$ ranges between 18 and $93 \mathrm{~h}$ per image, depending on each sample's signal strength. Details are given in the figure legends.

In the image slices, occasional single pixels with high signal intensity but no morphological context are an artifact originating from the Fourier transformation of frequency into spatial information. The apparent loss of signal intensity towards the edges of the Field of View (FOV) is due to the coil geometry employed to send and receive the radiofrequency signals. The images were visualized and processed with the help of ImageJ (available at http://rsb.info.nih.gov/ij; developed by Wayne Rasband, National Institutes of Health, Bethesda, MD).

\section{Results and discussion}

All five belemnite guards described here exhibit anomalous growth patterns, the beginning of which - as well as their presumptive endogenous or exogenous origins - are not observ-
A

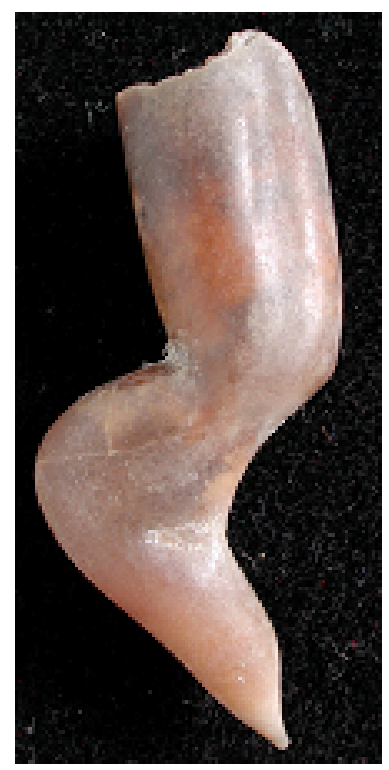

Fig. 1. Sublethal injury with fracture of the rostrum. Gonioteuthis quadrata (Blainville, 1827) guard with a zigzag-like deformation. (A): lateral view (photomicrograph). (B): median MR section. Arrow heads indicate fractures. The corresponding slice series (in steps of $125 \mu \mathrm{m}$ ) with this orientation is given in Movie 1. Acquisition parameters: Field of view (FOV): $15 \times 15 \times 32 \mathrm{~mm}^{3}$. Number of averages $\left(N_{A}\right): 2$. Total acquisition time $\left(T_{a}\right): 18 \mathrm{~h}$. Colour scale: MR signal intensity in arbitrary units (identical for all MR images). Scale bar: $5 \mathrm{~mm}$ for all MR image slices.

able externally, since subsequent calcitic lamellae cover the original disruption and obstruct the cause for its existence. In contrast, the presumed origins of the pathologies and their subsequent development of growth anomalies could be extracted non-invasively from the specimens by means of MR image series. The following anomalies have been recognised and their causality interpreted:

\subsection{Sublethal injury with fracture of the rostrum (Cat.-No. PB246)}

The complete, $33 \mathrm{~mm}$ long and up to $9 \mathrm{~mm}$ broad guard of Gonioteuthis quadrata shows a zigzag-like deformation (Fig. 1A). The MR image (Fig. 1B) revealed multiple internal fractures of the juvenile guard ( $\varnothing 5.1 \mathrm{~mm}$ in maximum) distally of the intact alveole. We conclude that, as the result of a probably sublethal bite of an unknown predator, the second fragment has been dislocated ventrally almost perpendicularly to the two neighbouring fragments, while the small final fragment of the distal tip of the rostrum shows only a tiny kink. A presumed fourth fracture cutting the small fragment near the distal tip produced no dislocation. The fractures healed after the dislocated fragments were fixed by the surrounding soft body which mainly consisted of mus- 
A

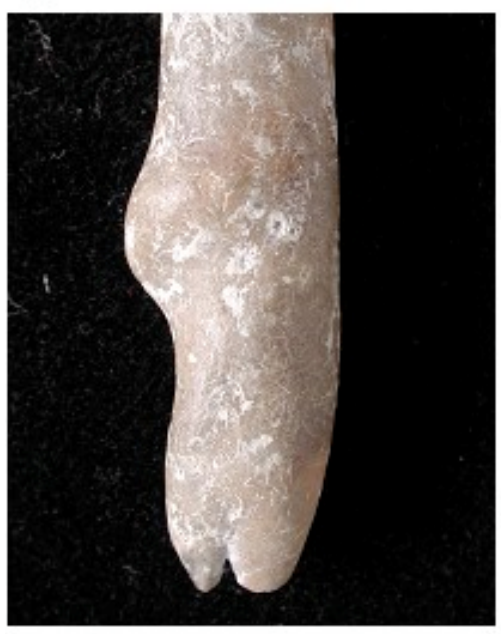

B

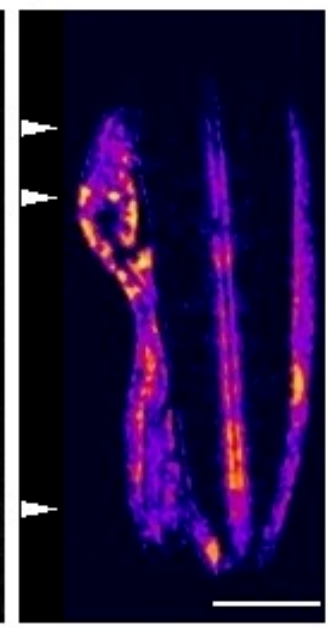

C

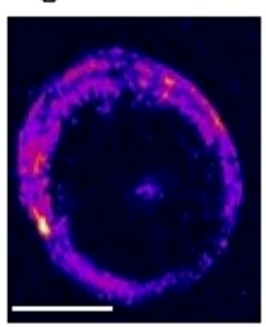
D

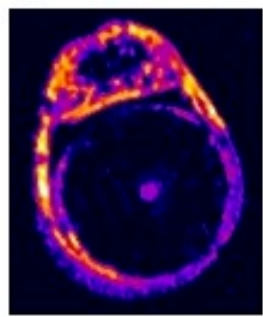

$\mathrm{E}$

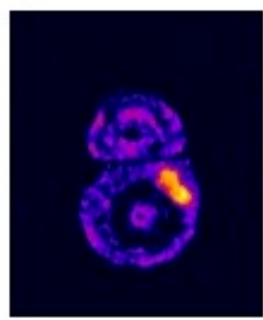

Fig. 2. Sublethal injury of the muscle mantle. Gonioteuthis quadrata (Blainville, 1827) guard with a twin apex. (A): lateral view (photomicrograph). (B): longitudinal MR section. Arrow heads indicate positions of the slices depicted in $(\mathrm{C})-(\mathrm{E})$. (C): transverse MR section through the beginning of the anomaly exhibiting the preceding injury of the interimistic guard's surface. (D): transverse MR section through the initial bulg. (E): transverse MR section through the double rostrum at the posterior part. The corresponding slice series (proximal to distal in steps of $109 \mu \mathrm{m}$ ) with transverse orientation is given in Movie 2. Acquisition parameters: FOV: $10 \times 12 \times 28 \mathrm{~mm}^{3} . N_{A}: 4 . T_{a}: 36 \mathrm{~h}$.

cles and tendons (Abel, 1916) and was then consecutively covered with several calcareous layers. The interim surface of the guard's fragments at the time of the traumatic attack is marked by sharp lines of high signal intensity, interpreted as representing a temporary interruption of the mineralization which triggered a higher incorporation of organic material. During regeneration, the secretion of new calcareous layers was partly asymmetrical. Inside the knee-like arrangement of the rostral fragments (i.e. dorsally), in particular, the thickness of single growth lines is enlarged, and accreted post-traumatic calcitic layers add up to $6.2 \mathrm{~mm}$ in thickness, whereas they are reduced on the convex part - only a $0.8 \mathrm{~mm}$ thick post-traumatic calcitic coating was added at the ventral part of the "knee". A very similar anomalous guard of $\mathrm{Hi}$ bolithes subfusiformis, described by Douval-Jouve (1841, cf. pl. 10, Fig. 17 in there) had recovered from a double-fracture by forming such a double-kinked rostrum.

3.2 Sublethal injury which only affected the muscle mantle around the guard (Cat.-No. PB248)

Two anomalous rostra of Gonioteuthis quadrata exhibit an apparent doubling of their pointed apexes. The $60 \mathrm{~mm}$ long and up to $9 \mathrm{~mm}$ wide guard PB248 developed, along the final $25 \mathrm{~mm}$ of the main guard, a second rostral element laterally, beginning with a bubble-like bulge of $9 \mathrm{~mm}$ length (Fig. 2A). The phenomenon corresponds with an apparent bifurcation of the rostrum in which the two branches - that originally developed separately and ran subparallel to each other - have in fact been connected in a later phase by common growth layers. The MR image (Figs. 2B-2E) shows very clearly that the surface of the juvenile guard inside $(\varnothing 7.6 \mathrm{~mm})$ was probably undamaged at the beginning of the anomaly. The irregular growth pattern from which the bulge arose at the onset of anomalous growth through subsequent thickening by new calcite layers can be interpreted as a disturbance of the calcite secreting mantle, most probably initiated by a traumatic event. The muscular mantle had in part been torn off, thereby isolating a small piece of it. Similar to the formation of a free pearl in mussels where an isolated fragment of the secreting epithelium provides the basis for the construction of the pearl sac (Götting, 1974; Keupp, 1987), this small piece was then the starting point for a second mantle fold during regeneration of the mantle tissue in which an additional rostrum could develop. The moment of the traumatic event is marked by a sharp growth line inside the entire guard, documenting again the phase of regeneration in which the mineralization process was temporarily interrupted and a distinct layer rich in organic matter inserted. Similar anomalous rostra with proliferate growth phenomena - by formation of separated mineralisation centres - have been described of a Jurassic Hibolithes (Keupp, 2002), while guards with two or multiple tips have repeatedly been reported (Keupp, 2002; Wundt, 1883; Schwegler, 1939; Finzel, 1963; Schmid, 1963; Miertzsch, 1964; Ladwig, 1993).

\subsection{Apical collar as a result of inflammation (Cat.-No. PB-} 249)

Another phenomenon frequently observed in Late Cretaceous belemnite guards of different taxa but not yet described is the development of a small collar-like rim in dorsal position above the rostral tip. The $75 \mathrm{~mm}$ long and up to $11 \mathrm{~mm}$ broad guard PB249 appears to have a double tip, owing to the close position of the anomalous dorsal collar to the normal tip of the rostrum (Fig. 3A). Yet it differs significantly from the real double tips described above. The MR image (Figs. 3B and 3C) reveals that the growth of the anomalous collar starts at the former surface of the guard with no visible damage and continues into a small hollow tunnel with an apical opening. The small tunnel resembles drainage channels for organic fluids of inflamed portions of tissue. Therefore, this characteristic anomaly of belemnite guards is presumed 
A

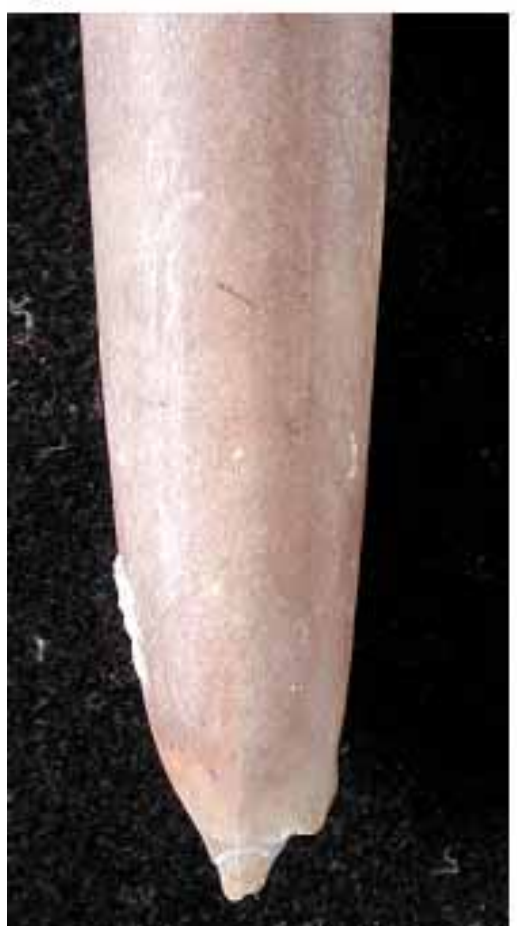

B

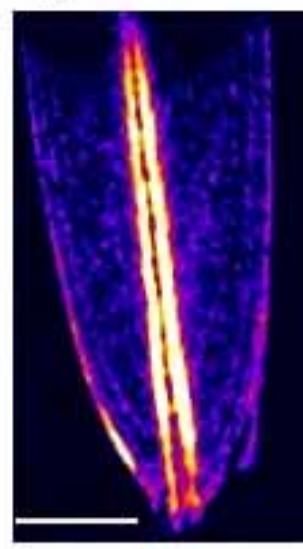

C

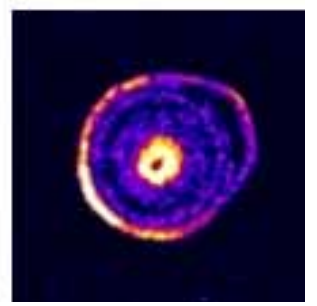

Fig. 3. Apical collar. Gonioteuthis quadrata (Blainville, 1827) guard with a collar-like dorsal anomaly. (A): lateral view (photomicrograph). (B): median MR section. (C): transverse MR section through the anomalous dorsal lip. The corresponding slice series (proximal to distal in steps of $109 \mu \mathrm{m}$ ) with transverse orientation is given in Movie 3. FOV: $12 \times 12 \times 28 \mathrm{~mm}^{3} . T_{r}: 852 \mathrm{~ms} . N_{A}: 12$. $T_{a}: 93 \mathrm{~h}$.

to have been initiated by a local infection or other inflammatory disturbances of the muscular mantle, perhaps also by settlement of a tiny parasite (see below).

3.4 Disturbance of the guard secreting mantle by presumed parasitism (Cat.-No. PB264)

Bubble-like protuberances of guards as depicted in Figs. 4 and 5 were very probably initiated by implantation of parasites. The $32 \mathrm{~mm}$ long rostrum of Neoclavibelus subclavatus exhibits a drop-sized bubble elevated up to $5 \mathrm{~mm}$ above the guard's normal surface and shows a growth direction towards the anterior part of the animal (Fig. 4A). The vertical and horizontal MR image sequences (Figs. 4B-4D) show a prominent growth line surrounding the juvenile guard at about $2.9 \mathrm{~mm}$ diameter. During subsequent thickening of the guard, the successive formation of an irregularly bordered cavity can be observed immediately above the tip of the interimistic surface of the guard. At the beginning and end of the increasing bubble-like anomaly, no signs of a preceding damage of the rostrum are recognisable (cf. Fig. 4D). The sharp concentric growth line circumscribing the undisturbed
A

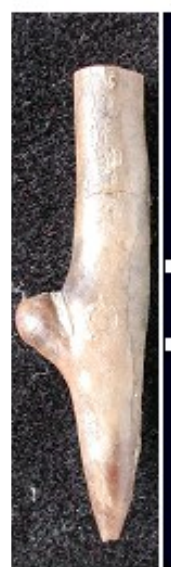

B

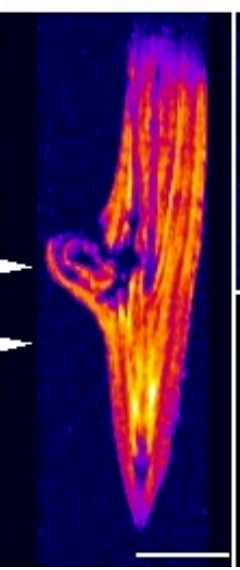

C

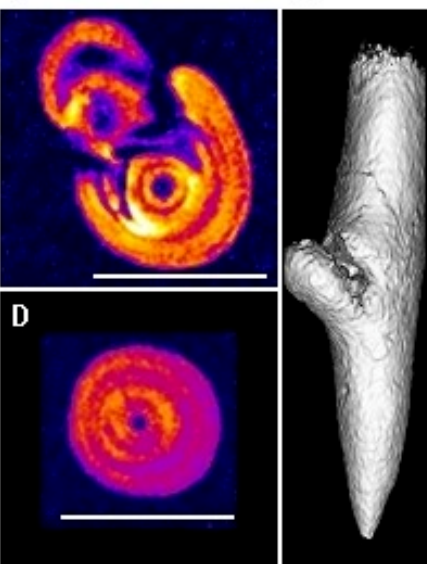

Fig. 4. Disturbance of the guard secreting mantle. Neoclavibelus subclavatus (Voltz, 1830) guard (collection of V. Kriegisch) with an anomalous protuberance, presumably caused by parasitism. (A): lateral view (photomicrograph). (B): median longitudinal MR section. Arrow heads indicate positions of the slices depicted in (C) and (D). (C): transverse MR section through the bubble-like anomaly. (D): more distal transverse MR section through normal tissue. The corresponding slice series (proximal to distal in steps of $117 \mu \mathrm{m}$ ) with transverse orientation is given in Movie 4. The radial lines are indicative of the direction of calcite crystal growth (E): 3D model of the guard, directly obtained from the MR images. FOV: $8 \times 8 \times 30 \mathrm{~mm}^{3} . T_{r}: 952 \mathrm{~ms} . N_{A}: 10 . T_{a}: 87 \mathrm{~h}$.

juvenile guard is therefore presumed to mark the temporary interruption of an otherwise rather continuous secreting activity of the muscular mantle in response to the infection by an unknown parasite. The protuberance of the guard probably results from the successively increasing proliferation of the endoparasite. A 3D model of the guard, as obtained from the MR images, is depicted in Fig. 4E.

\subsection{Early disturbance of the guard secreting mantle by pre-} sumed parasitism (Cat.-No. PB251)

A similar growth disturbance, probably also due to parasitism, is shown in Fig. 5. The surface of the $43 \mathrm{~mm}$ long and $7 \mathrm{~mm}$ wide rostrum (not including the anomaly) of $\mathrm{Hi}$ bolithes jaculoides is slightly corroded. An ovoid bubble elevates about $6.5 \mathrm{~mm}$ above the normal surface near the proximal part of the guard (Fig. 5A). The MR images (Figs. 5B and $\mathrm{C}$ ) suggest that the formation of the anomalous bubble began during an early ontogenetic stage and lead to the formation of an internal irregularly bordered cavity which enlarged the middle axis of the rostrum up to $7 \mathrm{~mm}$. The anomaly starts close to the empty alveole from which only the distal part is preserved, probably situated immediately after the primordial rostrum (invisible here). The internal cavernous structure seems to be divided into a proximal ovoid chamber of ca. $2 \mathrm{~mm}$ by $5 \mathrm{~mm}$, potentially reflecting the 
A

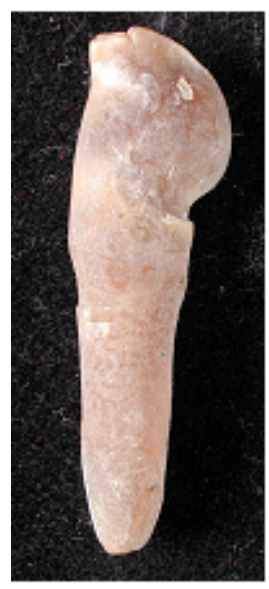

B

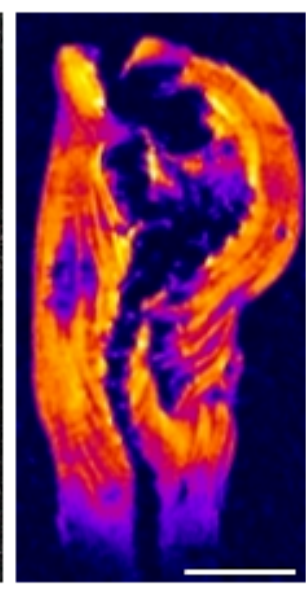

C

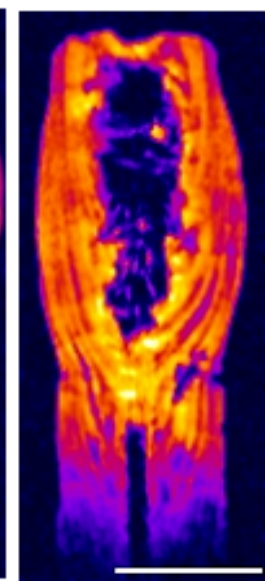

Fig. 5. Early disturbance of the guard secreting mantle. Anomalous rostrum of Hibolithes jaculoides (Swinnerton, 1937). (A): lateral view (photomicrograph). (B): median longitudinal MR section. (C): dorsal longitudinal MR section. The corresponding slice series (proximal to distal in steps of $113 \mu \mathrm{m}$ ) with transverse orientation is given in Movie 5. FOV: $13 \times 11 \times 29 \mathrm{~mm}^{3} . N_{A}: 4 . T_{a}: 36 \mathrm{~h}$.

original size of the encysted parasite itself, and a larger distal portion characterised by proliferous growth of irregular tissue without or with only slight calcitic mineralization.

\section{Conclusions}

Our study has shown that MR techniques allow to visualize structural details in fossils non-invasively. This is perhaps surprising on its own - fossils notoriously lack typical MRI contrast generators, namely water and soft tissue - but more striking is the observation that ordinary liquid state pulse sequences lead to reasonable image contrast in rock-solid mineralized materials. What is more, solid state techniques, at least in the belemnite samples we investigated, do not reach a comparable signal-to-noise ratio (data not shown). So the question is where the signal comes from. Fortunately, the anomalous samples already give some hints: First, signal intensity in the pathological regions is usually higher (cf. Figs. 2B and D) and rarely lower (cracks in Fig. 1B) than in the normal ones, thereby indicating that syn vivo reactions to the pathological incident laid the ground for the uneven signal distribution. This corresponds well with previous reports of higher organic contents in pathologically affected areas (Sælen, 1989). Second, the frequent observations of a hollow (as in PB264 and PB251) rostrum cavum have led to the suggestion that its primary content may have been organic (Bandel and Spaeth, 1988). Third, in cases where the innermost layer of the rostrum is not hollow, it gives a higher signal than its immediate surrounding (cf. Figs. 1 and 2). While this might equally point at taxonomic differences, it is compatible with the assumption that the image contrast in the belemnite MRI data mainly stems from differences in primary content of organic matter which was, perhaps, later partly replaced by diagenetic calcite. Fourth, the compact concentric layering of separate organic and inorganic layers in belemnites could provide an explanation for the presumed good conservation of organic matter within these structures. However, with the imaging parameters used, hydrogen nuclei of crystal water in inorganic materials can not usually be distinguished from hydrogen nuclei in organic molecules. This distinction would require additional experiments with different MR parameterization or complementary methods, and for the samples discussed here, the indication of catalogue numbers will facilitate such future comparative methodological studies.

The MR image data obtained from belemnite guards allowed to observe their small-scale three-dimensional growth lamellae and to consistently interpret origins and developments of internal structures in rostra experiencing ontogenetic or anomalous anatomical and physiological alterations. Furthermore, the notion that the apical collar might be indicative of an inflammatory disease illustrates that MR imaging can contribute to the generation or validation of hypotheses on belemnite pathologies. Finally, all traditional paleontological investigations still remain possible after MR scanning, which is not necessarily true in the reverse case. Preliminary studies suggest that MRI can successfully be applied to brachiure visualisation in brachiopod taxonomy, and based on the assumption that the contrast mainly stems from differences in organic matter contents, we estimate that many other types of samples will behave similarly when subjected to $\mathrm{MR}$, provided that they exhibit structures where organic and inorganic are arranged in closely intertwined but separate layers - e.g. the complex septal configurations in ammonites or internal structures of fossil wood, bones and teeth. Taken together, the microscopic resolution currently achieved with Magnetic Resonance techniques, their non-invasiveness, the possibility to obtain spectroscopic and 3D spatial information, their potentially broad applicability and the multitude of ongoing efforts to further improve them (Glover and Mansfield, 2002) all suggest they could provide helpful insights into a wide range of paleobiological issues, with the precious samples remaining intact.

\section{Supplementary information}

Movie 1: Sublethal injury with fracture of the rostrum in Gonioteuthis quadrata (Blainville, 1827).

Movie 2: Sublethal injury of the muscle mantle in Gonioteuthis quadrata (Blainville, 1827).

Movie 3: Apical collar in Gonioteuthis quadrata (Blainville, 1827).

Movie 4: Disturbance of the guard secreting mantle in Neoclavibelus subclavatus (Voltz, 1830). 
Movie 5: Early disturbance of the guard secreting mantle in Hibolithes jaculoides (Swinnerton, 1937).

Acknowledgements. We thank A. Schaeffer (Bickenbach, Germany), G. Gruber (Darmstadt, Germany), K. Engel (Frankfurt am Main, Germany), M. Aberhan (Berlin, Germany) and O. Hampe (Berlin, Germany) for helpful discussions during the preparation of this study. Furtheron, we thank C. Spaeth (Hamburg, Germany) and the private collectors, particularly V. Kriegisch (Schonungen, Germany) and D. Weise (Berg, Germany), for providing us with the anomalous guards.

Edited by: W. Kiessling

\section{References}

Abel, O.: Paläobiologie der Cephalopoden aus der Gruppe der Dibranchiaten, Jena, Gustav Fischer Verlag, 281 p., 1916.

Bandel, K., Engeser, T., and Reitner, J.: Die Embryonalentwicklung von Hibolites (Belemnitida, Cephalopoda), N. Jb. Geol. Paläont. Abh., 167, 275-303, 1984.

Bandel, K. and Spaeth, C.: Structural differences in the ontogeny of some belemnite rostra, in: Cephalopods present and past, edited by: Wiedmann, J. and Kullmann, J., Stuttgart, Schweizerbart Verlag, 247-271, 1988.

Battiato, A.: Su un sepiostario aberrante di Sepia officinalis L. (Cephalopoda, Sepiidae), Thalassia Sal., 12-13, 152-153, doi:10.1285/i15910725v12-13p152, 1983.

Bayer, U.: Anomalien bei Ammoniten des Aaleniums und Bajociums und ihre Beziehung zur Lebensweise, N. Jb. Geol. Paläont. Abh., 135, 19-41, 1970.

Bello, G. and Paparella, P.: The "woundrous" cuttlebone of Sepia orbignyana, Berliner Paläobiol. Abh., 1, 10-11, 2002.

Blümich, B. and Kuhn., W. (eds.): Magnetic resonance microscopy: methods and applications in materials science, agriculture and biomedicine, Weinheim, Basel, Cambridge, New York, VCH, 604 p., 1992.

Boesch, C.: Molecular aspects of magnetic resonance imaging and spectroscopy, Mol. Aspects Med., 20, 185-318, doi:10.1016/S0098-2997(99)00007-2, 1999.

Borah, B., Gross, G. J., Dufresne, T. E., Smith, T. S., Cockman, M. D., Chmielewski, P. A., Lundy, M. W., Hartke, J. R., and Sod, E. W.: Three-dimensional microimaging (MRmicroI and microCT), finite element modeling, and rapid prototyping provide unique insights into bone architecture in osteoporosis, Anat. Rec., 265, 2, 101-110, doi:10.1002/ar.1060, 2001.

Callaghan, P. T.: Principles of Nuclear Magnetic Resonance Microscopy. Clarendon, Oxford University Press, 492 p., 1991.

Clark, N. D., Adams, C., Lawton, T., Cruickshank, A. R., and Woods, K.: The Elgin marvel: using magnetic resonance imaging to look at a mouldic fossil from the Permian of Elgin, Scotland, UK, Magn. Reson. Imaging, 22, 2, 269-273, doi:10.1016/j.mri.2003.09.006, 2004.

Dietl, G. and Schweigert, G.: Im Reich der Meerengel. München, Verlag Dr. Friedrich Pfeil, 144 pp., 2001.

Duval-Jouve, J.: Bélemnites des terraines inférieures des environs de Castellane, Paris, Basses Alpes, 1841.

Engel, T.: Über kranke Ammonitenformen im schwäbischen Jura, Nova Acta Abh, K. Leop. Deutsch. Akad. Naturf., 61, 5, 326-
384 + Taf. XV-XVII, Halle, Kaiserlich Leopoldinische Deutsche Akademie der Naturforscher zu Halle, 1894.

Ernst, R. R., Bodenhausen, G., and Wokaun, A.: Principles of Nuclear Magnetic Resonance in One and Two Dimensions, Clarendon, Oxford University Press, 610 p., 1997.

Finzel, E.: Ein Zweispitz-Belemnit von Misburg - ein Unikum, Der Aufschluss, 14, 47, 1963.

Fischer, A. G.: A belemnoid from the Late Permian of Greenland, Medd. Grønl., 135, 5, 1-25, 1947.

Glover, P. and Mansfield, P.: Limits to magnetic resonance microscopy, Rep. Prog. Phys., 65, 1489-1511, doi:10.1088/00344885/65/10/203, 2002.

Götting, K.-J.: Malakozoologie, Stuttgart, Gustav Fischer Verlag, 320 pp., 1974.

Guex, J.: Contribution à l'étude des blessures chez les ammonites, Bull. Lab. Géol. Univ. Lausanne, 165, 1-16, 1967.

Hanai, T.: Lower Cretaceous Belemnites from Miyako District, Japan, Japan. J. Geol. Geogr., 23, 63-80, 1953.

Hengsbach, R.: Ammonoid Pathology, in: Ammonoid Paleobiology (Topics in Geobiology 13), edited by: Landman, N. H., New York, Plenum Press, 581-605, 1996.

Hölder, H.: Über Anomalien an jurassischen Ammoniten, Paläont. Z., 30, 95-107, 1956.

Jeletzky, J. A.: Comparative morphology, phylogeny, and classification of fossil Coleoidea, Univ. Kansas Paleontol. Contr., 7, $1-162,1966$.

Keupp, H.: Pathologische Ammoniten, Kuriositäten oder paläobiologische Dokumente, Teil 1, Fossilien, 1984, 6, 258-262 and 267-275, 1984.

Keupp, H.: Pathologische Ammoniten, Kuriositäten oder paläobiologische Dokumente, Teil 2, Fossilien, 1985, 1, 23-35, 1985.

Keupp, H.: Perlen (Schalenkonkretionen) bei Dactylioceraten aus dem fränkischen Lias, Natur u. Mensch, Jahresmitt. Naturhistor. Ges. Nürnberg, 1986, 97-102, 1987.

Keupp, H.: Ammoniten - Paläobiologische Erfolgsspiralen. Stuttgart, Thorbecke Verlag, 165 p., 2000.

Keupp, H.: Pathologische Belemniten - Schein und Wirklichkeit, Fossilien, 2002, 2, 85-92, 2002.

Kröger, B.: Schalenverletzungen an jurassischen Ammoniten ihre paläobiologische und paläoökologische Aussagefähigkeit, Berliner Geowiss. Abh. E, 33, 1-97, 2000.

Ladwig, J.: Pathologischer Belemnit aus der Oberkreide, Fossilien, 1993, 6, 332, 1993.

Lambert, J. B., Shawl, C. E., and Stearns, J. A.: Nuclear magnetic resonance in archaeology, Chem. Soc. Rev., 29, 175-182, doi:10.1039/a908378b, 2000.

Miertzsch, E.: Ein Belemnit mit fünf Spitzen, Der Aufschluss, 15, 3, 74, 1964.

Naef, A.: Die fossilen Tintenfische. Jena, Gustav Fischer Verlag, 322 pp., 1922.

O’Neill, B. R., Alakkam, A. A., Hays, P. D., and Manger, W. L.: Petrography of Jurassic belemnoid rostra, Utah, United States: Insights into rostrum secretion, Berliner Paläobiol. Abh. 1, 89, 2002.

Podlaha, O. G., Mutterlose, J., and Veizer, J.: Preservation of $\delta^{18} \mathrm{O}$ and $\delta^{13} \mathrm{C}$ in belemnite rostra from the Jurassic/Early Cretaceous successions, American J. Science, 298, 324-347, 1998.

Radwańska, U. and Radwański, A.: Disease and trauma in Jurassic 
invertebrate aminals of Poland - an updated review, Tomy Jurajskie (Warszawa) 2, 99-111, 2004.

Ruggiero, L.: Un esemplare aberrante di Sepia officinalis L. (Cephalopoda, Sepiidae), Thalassia Sal. 10, 131-132, doi:10.1285/i15910725v10p131, 1980.

Sælen, G.: Diagenesis and construction of the belemnite rostrum, Palaeontol., 32, 4, 765-798, 1989.

Schmid, F.: Ein Nachtrag zum "Zweispitz-Belemnit" aus dem Untercampan von Misburg bei Hannover, pathologische Ausbildung an Gonioteuthis quadrata (Blainville), Der Aufschluss, 14, 294296, 1963.

Schwegler, E.: Eine merkwürdige Krankheitserscheinung bei einem Belemniten aus dem Braunen Jura epsilon Schwabens und ihre Deutung, Zentralbl. Min. Geol. Pal., Abt. B, 74-80, 1939.

Siveter, D. J., Sutton, M. D., Briggs, D. E., and Siveter, D. J.: A Silurian sea spider, Nature, 431, 978-980, doi:10.1038/nature02928, 2004.

Spoor, F., Jeffery, N., and Zonneveld, F.: Imaging skeletal growth and evolution, in: Development, Growth and Evolution: Implications for the Study of the Hominid Skeleton, edited by: O'Higgins, P. and Cohn, M., London, Academic Press, 123-161, 2000.
Stevens, G. R.: The Jurassic and Cretaceous belemnites of New Zealand and a review of the Jurassic and Cretaceous belemnites of the Indo-Pacific Region, Paleontol. Bull. NZ Geol. Surv., 36, $1-283,1965$.

Tasnádi-Kubacska, A.: Paläopathologie, Jena, VEB Gustav Fischer Verlag, 269 pp., 1962.

Veizer, J.: Chemical diagenesis of belemnite shells and possible consequences of paleotemperature determinations, N. Jb. Geol. Paläont Abh., 147, 1, 91-111, 1974.

von Boletzky, S. and Overath, H.: Shell fracture and repair in the cuttlefish Sepia officinalis, in: La seiche, the cuttlefish, edited by: Boucaud-Camou, E., Caen, Centre de Publications, Université de Caen, 69-78, 1989.

Ward, P. and von Boletzky, S.: Shell implosion depth and implosion morphologies in three species of Sepia (Cephalopoda) from the Mediterranean Sea, J. mar. biol. Ass. UK, 64, 955-966, 1984.

Wundt, G.: Über die Vertretung der Zone des Ammonites transversarius im schwäbischen Weißen Jura, Jahrb. Ver. vaterl. Naturk. Württ., p. 96, 1883. 